\title{
A new cytotoxic and anti-fungal C-glycosylated benz[ $\alpha$ ]anthraquinone from the broth of endophytic Streptomyces blastomycetica strain F4-20
}

\author{
He Yan, Yang Li, Xing Y Zhang, Wan Y Zhou and Tao J Feng \\ The Journal of Antibiotics (2017) 70, 301-303; doi:10.1038/ja.2016.126; published online 2 November 2016
}

Endophytes reside in the tissues of living plants without exerting any pathogenic effects. ${ }^{1}$ Endophytes produce a great number of secondary metabolites with diverse chemical structures and various biological activities, which have been implicated in the protection of their hosts against pathogens and herbivores. ${ }^{2}$ Endophytic microorganisms are an excellent source of structurally diverse molecules with potential therapeutic value.

In this study, a new C-glycosylated benz $[\alpha]$ anthraquinone, dehydroxyaquayamycin B (1), along with two known alkaloids, teleocidin B2 (2) and N-methyl-L-valyl-L-tryptophanol (3), was isolated from the endophytic Streptomyces blastomycetica strain F4-20 (Figure 1). The new compound was tested for cytotoxic and antifungal activities. The strain F4-20 was isolated from the root of Tripterygium wilfordii Hook. f., a medicinal plant in China, by spreading on actinomyces isolation agar from Difco (Becton, Dickinson and Company, Franklin Lakes, NJ, USA), consisting of $0.05 \%$ dipotassium phosphate, $0.0001 \%$ ferrous sulfate, $0.01 \%$ magnesium sulfate, $0.05 \%$ sodium chloride, $0.1 \%$ potassium nitrate, $0.2 \%$ soluble starch and $1.5 \%$ agar, $\mathrm{pH} 7.2-7.4$, and incubated at $28^{\circ} \mathrm{C}$ for 7-14 days. The strain was identified as a member of the genus Streptomyces because its 16S rRNA sequence exhibited 99\% similarity to Streptomyces spectabilis NRRL B-5480, and has been deposited in the Research and Development Center of Biorational Pesticide, Northwest A\&F University, with the accession no. F4-20.

The strain was cultivated on the optimized solid medium containing glucose (Bei Jing Ao Bo Xing, Beijing, China) $20 \mathrm{~g}$, potato $200 \mathrm{~g}$, beef extract $10 \mathrm{~g}, \mathrm{KH}_{2} \mathrm{PO}_{4} 1 \mathrm{~g}$, ammonium sulfate $1 \mathrm{~g}, \mathrm{NaNO}_{3} 1 \mathrm{~g}, \mathrm{NH}_{4} \mathrm{Cl}$ $1 \mathrm{~g}$ and agar $17 \mathrm{~g}$ in $1.0 \mathrm{~L}$ tap water, $\mathrm{pH} 8.0-8.5$. The spore suspension was then filtered through six layers of sterile filter cheesecloth and adjusted to $10^{7}-10^{8} \mathrm{CFU} \mathrm{ml}{ }^{-1}$. A $2.0 \mathrm{ml}$ of the spore suspension was inoculated into a $250-\mathrm{ml}$ flask containing $100 \mathrm{ml}$ of seed medium consisting of glucose (Bei Jing Ao Bo Xing) $4 \mathrm{~g}$, malt extract powder (Cormwin, Beijing, China) $10 \mathrm{~g}$ and yeast autolysate (Bei Jing Ao Bo Xing) $4 \mathrm{~g}$ in $1.0 \mathrm{~L}$ tap water, $\mathrm{pH} 7.3$, and incubated at $28^{\circ} \mathrm{C}$ for $24 \mathrm{~h}$, with shaking at 140 r.p.m. Then, each $8.0 \mathrm{ml}$ of the cultured seed liquid were transferred into 340 250-ml Erlenmeyer flasks containing
$150 \mathrm{ml}$ of the sterile fermentation medium consisting of glucose (Bei Jing Ao Bo Xing) 0.4\%, malt extract powder (Cormwin, Beijing, China) $1 \%$ and yeast autolysate (Bei Jing Ao Bo Xing) 0.4\%, pH 7.3. Fermentation was carried out at $28^{\circ} \mathrm{C}$ for 7 days on a rotary shaker at 140 r.p.m.

The final $50 \mathrm{~L}$ of broth was filtered and evaporated under reduced pressure to $1 \mathrm{~L}$ at $55^{\circ} \mathrm{C}$ and the resulting concentrate was extracted three times using an equal volume of EtOAc. The EtOAc-soluble fraction (9.5 g) was applied to silica gel column (200-300 mesh; Qingdao Marine Chemical, Qingdao, China) eluting with a $\mathrm{CHCl}_{3}$ $\mathrm{MeOH}$ gradient (10:0, 20:1, 9:1, 8:2, 7:3, 1:1 and 0:1) to give five fractions A-E. The separation of fraction C (2.4 g) over silica gel column (200-300 mesh; Qingdao Marine Chemical) was eluted with petroleum ether-acetone $(30: 1-4: 1)$ to yield fractions C-1-C-7. Fraction C-3 $(0.21 \mathrm{~g})$ was subjected to a reversed-phase column (RP-18) eluting with $\mathrm{MeOH}$-water (20-90\%) to afford four subfractions (C-3-1-C-34). C-3-2 (0.08 g) was subjected to semipreparative reversed-phase HPLC (Shimadzu LC20A apparatus equipped with a UV detector and a Hypersil BDS $\mathrm{C}_{18}$ (Thermo, Shanghai, China; $250 \times 10 \mathrm{~mm}^{2}$ )) to give 1 $(29.7 \mathrm{mg})$ and 2 (2.4 mg). C-3-3 (0.017 g) was subjected to semipreparative reversed-phase HPLC to give $3(1.4 \mathrm{mg})$.

Compound $\mathbf{1}$ was isolated as an optically active amorphous red solid. Its molecular formula $\mathrm{C}_{37} \mathrm{H}_{42} \mathrm{O}_{11}$ was determined by the ESI-HRMS (API QSTAR Pulsar mass spectrometer; VG, Manchester, UK), owing to the presence of a pseudomolecular ion peak at $\mathrm{m} / \mathrm{z}$ 685.2623 $[\mathrm{M}+\mathrm{Na}]^{+}$(calcd. for $\mathrm{C}_{37} \mathrm{H}_{42} \mathrm{O}_{11} \mathrm{Na}, 685.2625$ ). The IR spectrum (Tensor 27 FT-IR spectrometer with $\mathrm{KBr}$ pellets) showed absorption bands at 3387, 1686, 1590, 1281 and $1268 \mathrm{~cm}^{-1}$, indicative of the existence of hydroxyl and carbonyl groups. Analysis of the ${ }^{13} \mathrm{C}$ and DEPT NMR spectra (DRX-500, $\left.{ }^{1} \mathrm{H}: 500 \mathrm{MHz} ;{ }^{13} \mathrm{C}: 125 \mathrm{MHz}\right)$ revealed the presence of two ketone carbonyl groups $\left(\delta_{\mathrm{C}} 188.25\right.$, C-7 and $\delta_{\mathrm{C}}$ 189.93, C-12), $10 s p^{2}$ quaternary, $6 s p^{2}$ methine, $10 s p^{3}$ methine, $5 s p^{3}$ methylene and $4 s p^{3}$ methyl carbons. The ${ }^{1} \mathrm{H}$ NMR spectrum of 1 also showed 19 well-resolved resonances that comprised of $6 s p^{2}$-hybridized methines, $10 s p^{3}$-hybridized methines, $5 s p^{3}$ methylene and $4 s p^{3}$-hybridized methyls, consistent with an

Research \& Development Center of Biorational Pesticide, Northwest A\&F University, Yangling, China

Correspondence: Professor JT Feng, Research and Development Center of Biorational Pesticide, Northwest A\&F University, Yangling 712100, China.

E-mail: fengjt67@hotmail.com

Received 7 May 2016; revised 28 August 2016; accepted 5 September 2016; published online 2 November 2016 


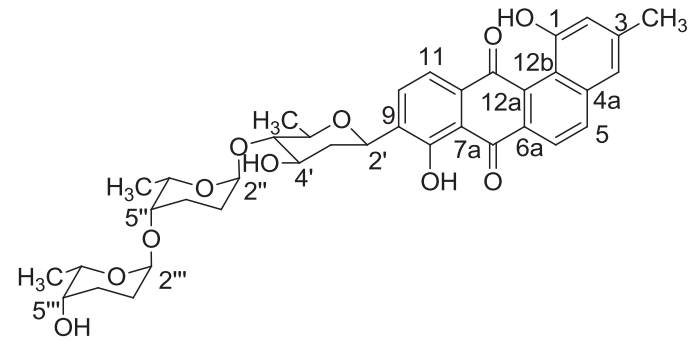

1

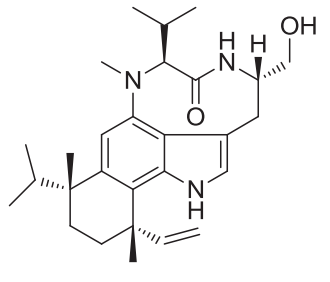

2

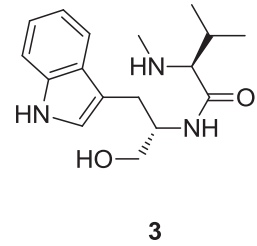

Figure 1 Chemical structures of dehydroxyaquayamycin B (1), teleocidin B2 and $\mathrm{N}$-methyl-L-valyl-L-tryptophanol.

angucycline core and three glycosidic residues. Two broad singlets at $\delta_{\mathrm{H}} 12.70$ and 11.45 , representing peri-hydroxy groups, and two 1,2,3,4-tetrasubstituted aromatic moieties were revealed by two $\mathrm{AB}$ systems $\left(\delta_{\mathrm{H}} 7.92\right.$ and $\delta_{\mathrm{H}} 7.97, \delta_{\mathrm{H}} 8.18$ and $\left.\delta_{\mathrm{H}} 8.36\right)$. Two additional broad aromatic signals, each ${ }^{1} \mathrm{H}$, at $\delta 7.19$ and 7.30 , showed another highly substituted aromatic ring with two $m$-coupled aromatic protons. Furthermore, a singlet of an aromatic-bound methyl group was observed at $\delta_{\mathrm{H}} 2.54$. The ${ }^{1} \mathrm{H}$ and ${ }^{13} \mathrm{C}$ NMR also revealed the presence of three saccharide moieties (three anomeric ${ }^{1} \mathrm{H}$ singlets, $\delta_{\mathrm{H}}$ 5.10-4.89) (Table 1). The HMBC spectrum displayed correlations from the $s p^{3}$ methine proton at $\delta_{\mathrm{H}} 4.96\left(\mathrm{H}-2^{\prime}\right)$ to two carbons at $\delta_{\mathrm{C}}$ 137.9 (C-9) and 133.3 (C-10), suggesting a C-glycosidic linkage. Further examination of these NMR data exhibited comparability of dehydroxyaquayamycin, ${ }^{3}$ which was originally obtained upon successive hydrogenation and acidification of aquayamycin. The only difference between compound $\mathbf{1}$ and dehydroxyaquayamycin was the longer saccharide moiety at C-9 position.

The saccharide moieties were deduced from detailed analyses of the one- and two-dimensional NMR data $\left({ }^{1} \mathrm{H}-{ }^{1} \mathrm{H}\right.$ COSY, HMQC, HMBC and NOESY spectra) of 1 . The anomeric proton at $\delta 4.96$ (d, $J=11.2 \mathrm{~Hz}, \mathrm{H}-2^{\prime}$ ) showed large coupling constant and thus represented $\beta$-D-glycoside moieties. The remaining two anomeric protons at $\delta_{\mathrm{H}} 5.10$ (brs, $\mathrm{H}-2^{\prime \prime}$ ) and $\delta_{\mathrm{H}} 4.89$ (brs, $\mathrm{H}-2^{\prime \prime \prime}$ ) were $\alpha$-glycosidically linked L-sugars. The COSY spectrum revealed the spin systems extending from $\mathrm{H}-2^{\prime}$ to $\mathrm{H}^{-} 7^{\prime}$ and $\mathrm{HMBC}$ spectrum displayed correlations from the $s p^{3}$ methine proton at $\delta_{\mathrm{H}} 4.87\left(\mathrm{H}-2^{\prime \prime}\right)$ to two carbons at $\delta_{\mathrm{C}} 137.9$ (C-9) and 133.3 (C-10). The latter suggested that this $\beta$-D-glycoside moiety was linked at the C-9 position. The dd peak at $\delta_{\mathrm{H}} 3.25\left(\mathrm{H}-5^{\prime}\right)$ gave coupling constants of 8.87 and $8.87 \mathrm{~Hz}$, indicating the axial orientation. Hence, the methyl at C-7' and two hydroxyl protons at C-4' and C-5' are in equatorial positions. NOESY spectrum, showing the cross-peak correlations from $\mathrm{H}_{\mathrm{ax}}-2^{\prime}$ to $\mathrm{H}_{\mathrm{eq}}-4^{\prime}$ and $\mathrm{H}_{\mathrm{ax}}-6^{\prime}$, also confirmed the above assumption. Thus, the first hexose moiety that linked to C-9 by a C-glycosidic linkage was identified as a $\beta$-D-olivose unit. The COSY spectrum also revealed the spin systems extending from $\mathrm{H}-2$ " to $\mathrm{H}-7^{\prime \prime}$. Wide single peaks at $3.60\left(\mathrm{H}-5^{\prime \prime}\right)$ indicated the equatorial orientation of this
Table $1{ }^{1} \mathrm{H}$ and ${ }^{13} \mathrm{C}$ NMR spectral data (in acetone- $d_{6}$ ) of dehydroxyaquayamycin $\mathrm{B}$

\begin{tabular}{|c|c|c|}
\hline Position & ${ }^{1} H N M R$ (p.p.m., $J$ in $\left.H z\right)$ & ${ }^{13} \mathrm{C} N M R$ (p.p.m.) \\
\hline 1 & & $155.43(\mathrm{~s})$ \\
\hline 2 & $7.19(\mathrm{~s})$ & 120.12 (d) \\
\hline 3 & & $142.05(\mathrm{~s})$ \\
\hline 4 & $7.30(\mathrm{~s})$ & $121.20(\mathrm{~d})$ \\
\hline $4 a$ & & $134.86(\mathrm{~s})$ \\
\hline 5 & $8.18\left(\mathrm{~d}, J=8.5 \mathrm{~Hz},{ }^{1} \mathrm{H}\right)$ & 137.57 (d) \\
\hline 6 & $8.36\left(\mathrm{~d}, J=8.6 \mathrm{~Hz},{ }^{1} \mathrm{H}\right)$ & $121.85(d)$ \\
\hline $6 a$ & & 139.19 (s) \\
\hline 7 & & $188.25(\mathrm{~s})$ \\
\hline $7 a$ & & $114.01(\mathrm{~s})$ \\
\hline 8 & & $157.94(\mathrm{~s})$ \\
\hline 9 & & $138.54(\mathrm{~s})$ \\
\hline 10 & $7.97(\mathrm{~d}, J=7.8 \mathrm{~Hz}, 2 \mathrm{H})$ & $133.58(d)$ \\
\hline 11 & $7.92(\mathrm{~d}, J=7.8 \mathrm{~Hz}, 2 \mathrm{H})$ & $121.40(d)$ \\
\hline $11 a$ & & $133.42(\mathrm{~s})$ \\
\hline 12 & & $189.93(\mathrm{~s})$ \\
\hline $12 a$ & & $132.52(\mathrm{~s})$ \\
\hline $12 b$ & & $120.12(\mathrm{~s})$ \\
\hline 13 & 2.54 (overlap) & $21.25(q)$ \\
\hline $2^{\prime}$ & $4.96\left(\mathrm{~d}, J=11.2 \mathrm{~Hz},{ }^{1} \mathrm{H}\right)$ & $71.22(d)$ \\
\hline \multirow[t]{2}{*}{$3^{\prime}$} & 1.54 (overlap) & $37.59(\mathrm{t})$ \\
\hline & 2.56 (overlap) & \\
\hline $4^{\prime}$ & $3.78\left({ }^{1} \mathrm{H}, \mathrm{m}\right)$ & $82.29(d)$ \\
\hline $5^{\prime}$ & $3.25(1 \mathrm{H}, \mathrm{dd}, J=8.87,8.87 \mathrm{~Hz})$ & $76.21(d)$ \\
\hline $6^{\prime}$ & $3.56\left({ }^{1} \mathrm{H}, \mathrm{m}\right)$ & $76.21(d)$ \\
\hline $7^{\prime}$ & $1.50\left({ }^{3} \mathrm{H}, \mathrm{d}, J=5.8 \mathrm{~Hz}\right)$ & 18.46 (q) \\
\hline $2^{\prime \prime}$ & $5.10\left({ }^{1} \mathrm{H}\right.$, brs $)$ & $97.61(d)$ \\
\hline \multirow[t]{2}{*}{$3^{\prime \prime}$} & 1.62 (overlap) & $25.45(t)$ \\
\hline & 2.13 (overlap) & \\
\hline \multirow[t]{2}{*}{$4^{\prime \prime}$} & 1.83 (overlap) & 24.27 (d) \\
\hline & 2.05 (overlap) & \\
\hline $5^{\prime \prime}$ & $3.60\left({ }^{1} \mathrm{H}, \mathrm{brs}\right)$ & 74.56 (d) \\
\hline $6^{\prime \prime}$ & $4.19\left({ }^{1} \mathrm{H}, \mathrm{m}\right)$ & $67.97(d)$ \\
\hline $7^{\prime \prime}$ & $1.27\left({ }^{3} \mathrm{H}, \mathrm{d}, J=6.4 \mathrm{~Hz}\right)$ & $17.04(q)$ \\
\hline $2^{\prime \prime \prime}$ & $4.89\left({ }^{1} \mathrm{H}, \mathrm{d}, J=1.5\right)$ & 99.55 (d) \\
\hline \multirow[t]{2}{*}{$3^{\prime \prime \prime}$} & 1.75 (overlap) & $23.57(\mathrm{t})$ \\
\hline & 2.00 (overlap) & \\
\hline \multirow[t]{2}{*}{$4^{\prime \prime \prime}$} & 1.82 (overlap) & $25.96(t)$ \\
\hline & 2.12 (overlap) & \\
\hline $5^{\prime \prime \prime}$ & $3.65\left({ }^{1} \mathrm{H}, \mathrm{brs}\right)$ & $67.46(5)$ \\
\hline $6^{\prime \prime \prime}$ & $4.08\left({ }^{1} \mathrm{H}, \mathrm{m}\right)$ & $66.84(d)$ \\
\hline $7^{\prime \prime \prime}$ & $1.21\left(\mathrm{~d}, J=6.5 \mathrm{~Hz},{ }^{3} \mathrm{H}\right)$ & $17.04(q)$ \\
\hline
\end{tabular}

proton. In consideration of NOESY cross-peak correlations from $\mathrm{H}_{\mathrm{ax}}-3^{\prime \prime}$ to $\mathrm{H}_{\mathrm{eq}}-2^{\prime \prime}$ and $\mathrm{H}_{\mathrm{ax}}-6^{\prime \prime}$, this hexose moiety could be deduced to L-rhodinose. The last sugar showed the same signal patterns and connectivity as L-rhodinose. HMBC correlations were used to establish the structure of the side chains and their points of attachment. The anomeric proton $\left(\delta_{\mathrm{H}} 4.96\right)$ of the olivose moiety showed an $\mathrm{HMBC}$ correlation to C-9 $\left(\delta_{\mathrm{C}} 137.9\right)$ and $133.3(\mathrm{C}-10)$ of the aglycone, whereas an $\mathrm{HMBC}$ correlation between the anomeric proton of the second L-rhodinose moiety $\left(\delta_{\mathrm{H}} 5.10\right)$ and the carbon at $\delta_{\mathrm{C}} 76.21$ $\left(\mathrm{C}-5^{\prime}\right)$, indicating that the second as rhodinose unit was attached to $\mathrm{C}-5^{\prime}$ of the olivose. The anomeric protons of the third L-rhodinose moiety $\left(\delta_{\mathrm{H}} 4.89\right)$ showed HMBC correlations to C-5" $\left(\delta_{\mathrm{C}} 74.56\right)$ of the second L-rhodinose unit, indicating that the third as a rhodinose unit was attached to $\mathrm{C}-5^{\prime \prime}$ of the second L-rhodinose (Figure 2). Thus, the 

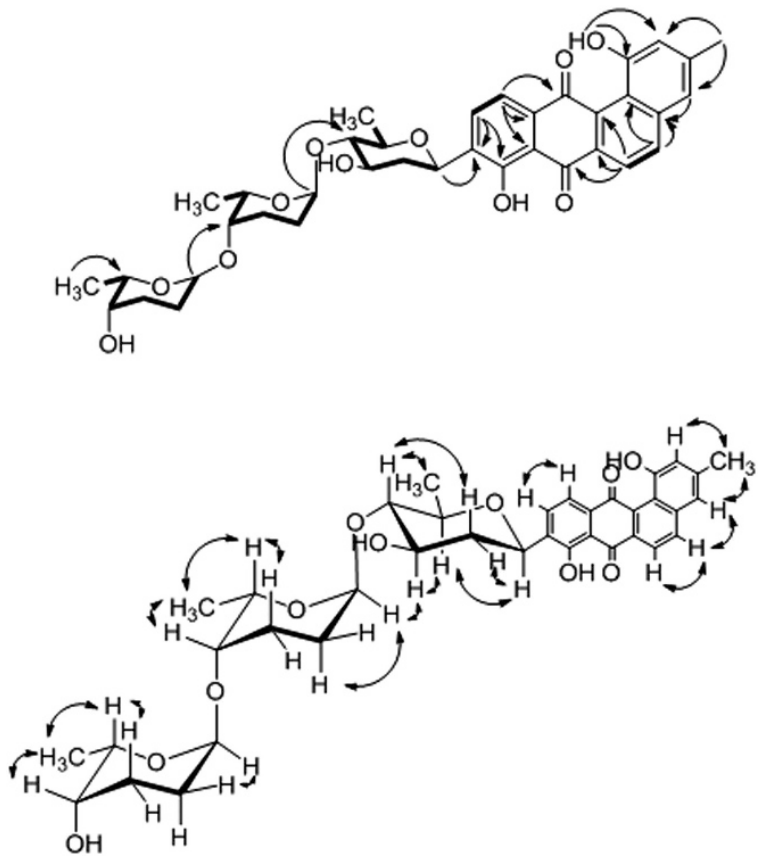

Figure $2 \mathrm{HMBC}$ connectivities $(\rightarrow),{ }^{1} \mathrm{H},{ }^{1} \mathrm{H}$ COSY correlations (bold lines) and diagnostic NOESY couplings $(\leftarrow \rightarrow)$ of dehydroxyaquayamycin B (1).

Table 2 Fungicidal activities of 1 with $50 \mu \mathrm{g} \mathrm{ml}-1$

\begin{tabular}{llc}
\hline Compound & Fungals & Inhibition rate (\%) \\
\hline 1 & Valsa mali & 41.45 \\
& Colletotrichum orbiculare & 58.33 \\
& Fusarium graminearum & 51.00 \\
& Rhizoctonia cerealis & 1.02 \\
& Botrytis cinerea & 2.10 \\
& Sclerotinia sclerotiorum & 1.87 \\
& Penicillium italicum & 2.32 \\
\hline
\end{tabular}

gross structure of $\mathbf{1}$ was assigned as shown in Figure 1, and this new compound was named as dehydroxyaquayamycin B.

Cytotoxicity of compound 1 against cancer cell lines BGC-823 and HeLa were tested using the MTT (3-(4,5-dimethylthiazol-2-yl)-2,5diphenyltetrazolium bromide) Kit (Promega, Madison, WI). In these tests, dehydroxyaquayamycin B showed strong inhibitory activity on the proliferation of BGC-823 and HeLa cells with the half maximal inhibitory concentration $\left(\mathrm{IC}_{50}\right)$ value of 0.71 and $1.34 \mu \mathrm{g} \mathrm{ml}^{-1}$, respectively.

Fungicidal activities of the compound $\mathbf{1}$ against Valsa mali, Colletotrichum orbiculare, Fusarium graminearum, Rhizoctonia cerealis, Botrytis cinerea, Sclerotinia sclerotiorum and Penicillium italicum were evaluated in vitro using the mycelium growth rate method ${ }^{4}$ with $50 \mu \mathrm{g} \mathrm{ml}^{-1}$ (Table 2). The results are given in Table 2. Results indicated dehydroxyaquayamycin B showed appreciable anti-fungal activity against $V$. mali, $C$. orbiculare and $F$. graminearum with the inhibition rate of $41.5 \%, 58.3 \%$ and $51.0 \%$, respectively.

Dehydroxyaquayamycin B is a benz $[\alpha]$ anthracene glycoside with a C-glycosidic substituent on C-9 position. Benz $[\alpha]$ anthraquinones have been isolated from various actinomycetes, especially in the genus Streptomyces. The first benz $[\alpha]$ anthraquinones, tetrangomycin and tetrangulol, were isolated from Streptomyces rimosus in 1966.
These type of compounds have gathered attention because of their structural diversity and significant biological activity. Biological activities of benz $[\alpha]$ anthraquinones such as anti-Helicobacter pylori ${ }^{5}$ anti-fungal, ${ }^{6}$ anti-Gram-positive bacterial, ${ }^{7,8}$ anticancer, ${ }^{9}$ anti-bacterial $^{10}$ activities have been reported. For example, urdamycins, isolated from Streptomyces fradiae strain $\mathrm{Tu} 2717$, displayed biological activities including inhibition of platelet aggregation, anti-microbial activity for Gram-positive bacteria and anticancer against stem cells of murine L1210 leukemia. ${ }^{9}$

Naturally occurring C-glucosylated benz $[\alpha]$ anthraqinones at C-9 such as YM-181741 from Streptomyces sp. showed anti-Helicobacter pylori activity with an minimum inhibitory concentration value of $0.2 \mathrm{mg} \mathrm{ml}^{-1}$, but was inactive against Gram-positive and -negative bacteria. ${ }^{5}$ Urdamycinones E, G and dehydroxyaquayamycin exhibited antimalarial and antitubercular activities. ${ }^{3}$

Dehydroxyaquayamycin B exhibited considerably cytotoxic activities on the proliferation of BGC-823 and HeLa cells with the $\mathrm{IC}_{50}$ value of 0.71 and $1.34 \mu \mathrm{g} \mathrm{ml}^{-1}$, respectively. It should be noted that naturally occurring C-glucosylated benz $[\alpha]$ anthraqinones such as urdamycinone $\mathrm{E}$, urdamycinone $\mathrm{G}$, dehydroxyaquayamycin and urdamycin $\mathrm{E}$ also possess strong cytotoxic activities with $\mathrm{IC}_{50}$ value of 0.092 and $0.242 \mu \mathrm{g} \mathrm{ml}^{-1}$ against NCI-H187 cells, revealing a promising potential of C-glucosylated benz $[\alpha]$ anthraqinones as new lead compounds for antitumor. Dehydroxyaquayamycin B also showed an appreciable anti-fungal activity against V. mali, C. orbiculare and F. graminearum, and this was the first report of fungicidal activities of C-glycosylated benz $[\alpha]$ anthraquinones.

In conclusion, the natural product dehydroxyaquayamycin $\mathrm{B}$ is a new benz $[\alpha]$ anthracene glycoside that was isolated from the the broth of endophytic S. blastomycetica strain F4-20. Dehydroxyaquayamycin B showed considerable cytotoxic activities. The results presented in this paper highlighted endophytic actinomycetes as a rich source of bioactive compounds, and this was the first report of the secondary metabolites of Streptomyces blastomycetica genus.

\section{CONFLICT OF INTEREST}

The authors declare no conflict of interest.

\section{ACKNOWLEDGEMENTS}

This work was financially supported by National Key Technology Support Program (No. 2014BAD23B01).

1 Siriwach, R. et al. Xylaropyrone, a new gamma-pyrone from the endophytic fungus Xylaria feejeensis MU18. J. Antibiot. 64, 217-219 (2011).

2 Shiono, Y. et al. A new benzoxepin metabolite isolated from endophytic fungus Phomopsis sp. J. Antibiot. 62, 533-535 (2009).

3 Supong, K. et al. Antimalarial and antitubercular C-glycosylated benz alpha anthraquinones from the marine-derived Streptomyces sp BCC455 96. Phytochem. Lett. 5, 651-656 (2012).

4 Chen, G., Zhou, Y., Cai, C., Lu, J. \& Zhang, X. Synthesis and antifungal activity of benzamidine derivatives carrying 1,2,3-triazole moieties. Molecules 19, 5674-5691 (2014).

5 Taniguchi, M. et al. YM-181741, a novel benz a anthraquinone antibiotic with anti-Helicobacter pylori activity from Streptomyces sp. J. Antibiot. 55, 30-35 (2002).

6 Nagasawa, T., Fukao, H., Irie, H. \& Yamada, H. Sakyomicins A, B, C and D: new quinone-type antibiotics produced by a strain of Nocardia. Taxonomy, production, isolation and biological properties. J. Antibiot. 37, 693-699 (1984).

7 Uchida, T. et al. Saquayamycins, new aquayamycin-group antibiotics. J. Antibiot. 38, 1171-1181 (1985).

8 Imamura, N., Kakinuma, K., Ikekawa, N., Tanaka, H. \& Omura, S. Biosynthesis of vineomycins A1 and B2. J. Antibiot. 35, 602-608 (1982).

9 Drautz, H., Zahner, H., Rohr, J. \& Zeeck, A. Metabolic products of microorganisms. 234. Urdamycins, new angucycline antibiotics from Streptomyces fradiae. I. Isolation, characterization and biological properties. J. Antibiot. 39, 1657-1669 (1986).

10 Igarashi, M. et al. Ochracenomicin-a, ochracenomicin- $b$ and ochracenomicin- $c$, new $[\alpha]$ anthraquinone antibiotics from Amicolatopsis sp. J. Antibiot. 48, 335-337 (1995). 